\title{
Lower Silurian graptolite zonation in the eastern Yangzi (Yangtze) Gorges, China
}

\author{
WANG XIAOFENG
}

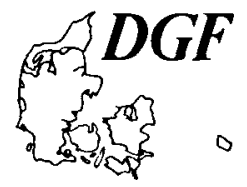

\begin{abstract}
Wang Xiaofeng. Lower Silurian graptolite zonation in the eastern Yangzi (Yangtze) Gorges, China. Bull. geol. Soc. Denmark, vol 35, pp. 231-243, July 1st, Copenhagen.

The Silurian in the eastern Yangzi Gorges is divided into the Longmaxi, Loreiping and Shamao Formations. Eleven graptolite zones, namely, the persculptus Zone, acuminatus Zone, vesiculosus Zone, acinaces Zone, cyphus Zone, triangulatus Zone, magnus-thuringiacus Zone, argenteus Zone, convolutus Zone, sedgwickii Zone and arcuatus Zone, are recognized from the Longmaxi Formation and the Lower Member of the Loreiping Formation at Wangjiawan section, near Yichang. The 'late Silurian' graptolites reported from the lower part of the Shamao Formation are revised. In the equivalent level C. nebula, $M$. cf. drepanoformis, Pr. variabilis and $M$. marri etc. have been found. The graptolite sequence across the Ordovician-Silurian boundary and its international correlation is further discussed.
\end{abstract}

Yichang Institute of Geology and Mineral Resources, Chinese Academy of Geological Sciences, Yichang, Hubei, China. August 29 th 1985.

\section{Introduction}

The Silurian System of the eastern Yangzi (Yangtze) Gorges has remained the focus for studying the Silurian biostratigraphy of China since the pioneering works given by Lee C. C. and Chao Y. T. (1924) and Hsich C. Y. and Chao Y. T. (1925). Numerous workers mentioned or discussed the Silurian divisions and various fossils in it. The first studies on graptolites were made by Sun (1933) and Hsü (1934), and later by Mu $(1959,1962)$. More systematical descriptions and discussions of both stratigraphy and fossils were carried out by Nanjing Institute of Geology and Palaeontology (1974), Ni (1978) and Ge et al. (1979) in nearby Loreiping, Yichang and by Wang (1978) at Fenxiang, Yichang. The Silurian strata of present area are widespread around the Huanglin anticline (Fig. 1). They are divided into the Longmaxi, Loreiping and Shamao Formations in ascending order. The most representive section lies at Wangjiawan, near Loreiping, the second at Fenxiang. They are $42 \mathrm{~km}$ and $31 \mathrm{~km}$ NNE of Yichang City, respectively, and rich in various fossils, such as graptolites, brachiopods, trilobites, corals, conodonts, cephalopods and bivalves. The graptolites mainly occur in the Longmaxi Formation. The Loreiping and Shamao Formations, characterized by yielding a number of shelly fossils, yielded only a few grap- tolites. Based on the researches of the Wangjiawan, Fenxiang and neighboring sections, the latest Ordovician to Silurian graptolite zonation of present area and their correlation are discussed in this paper.

\section{Longmaxi Formation}

The Longmaxi Formation is composed of $622.9 \mathrm{~m}$ of black and yellowish-green graptolitic shale. Its base is coincident with the first occurrence of the G. persculptus zone, which is attributed to the latest Ordovician according to a decision on the Ordovician and Silurian boundary, ratified by the international Commission of Stratigraphy and IUGS. Its top which is the lower part of the Loreiping Formation is drawn at the appearance of abundant shelly fossil-bearing silty mudstone with nodules. The Longmaxi Formation is further divided into a lower Black Shale Member, and an upper Yellowish-green Shale Member (Yan and Wang, 1978).

\section{Black Shale Member}

This member is a set of black shale, about $51.9 \mathrm{~m}$ thick, the upper part of which gradually weathers into grey black shale, and contains abundant graptolites. Eight graptolite zones can be recognized at Wangjiawan section in descending order: 


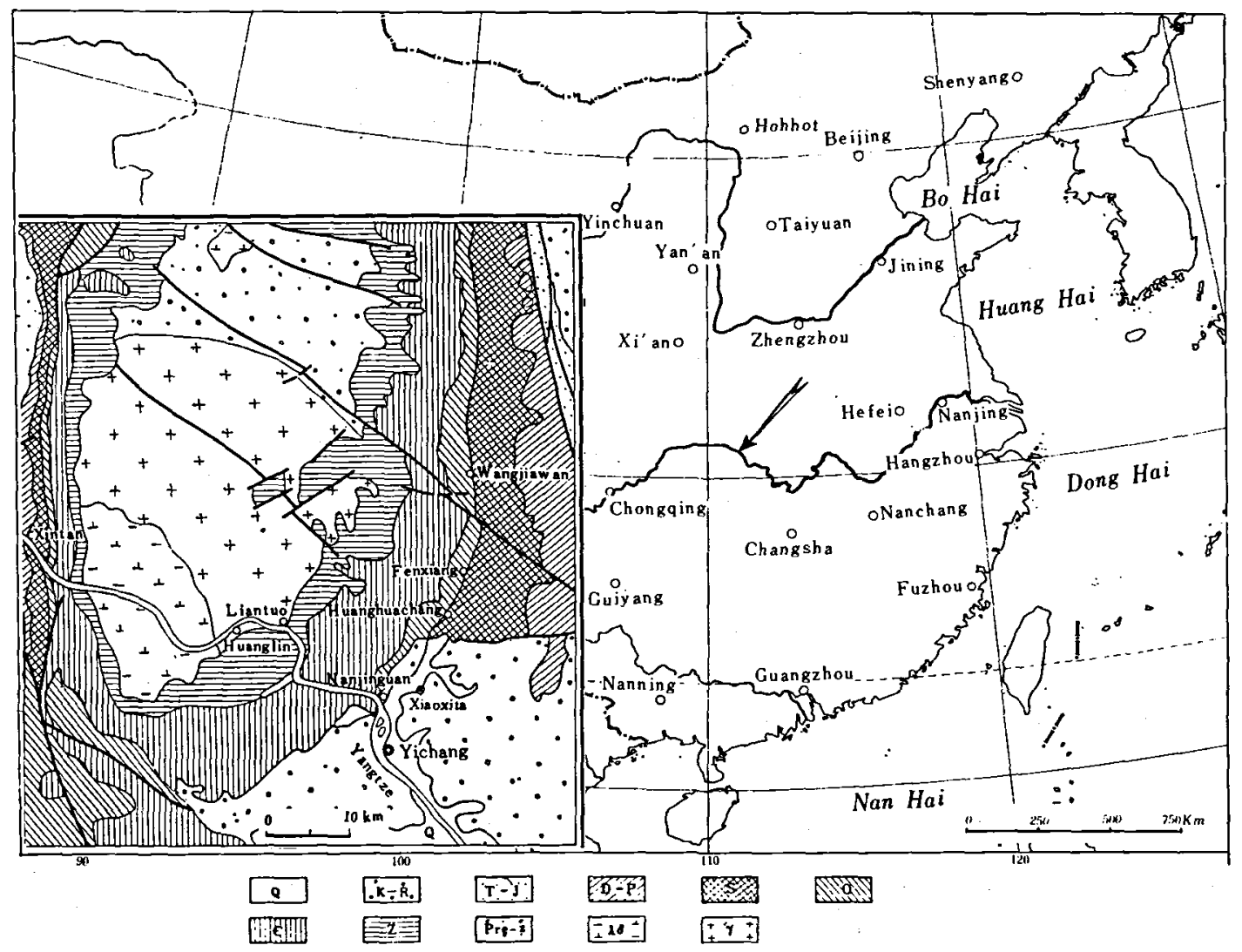

Fig. $1 \mathrm{a}-\mathrm{b}:$ Geographical and geological position of the sections in the eastern Yangtze Gorges. a - Geographical outlines; b - geological map.

Pernerograptus argenteus Zone

Diplograptus magnus-D. thuringiacus Zone

Demirastrites triangulatus Zone

Coronograptus cyphus Zone

Logarograptus acinaces Zone

Orthograptus vesiculosus Zone

Parakidograptus acuminatus Zone

Glyptograptus persculptus Zone

The Glyptograptus persculptus Zone

This zone is $0.32 \mathrm{~m}$ thick and is characterized by the appearance of $G$. persculptus Salter, associated with $G$. gracilis $\mathrm{Ge}, G$. maderni Koren et Mikhaylova, and Climacograptus angustus Perner at Wangjiawan section. Akidograptus ascensus occurs rarely in the upper part. In addition, Paraorthograptus cf. typicus ( $=P$. cf. pacificus Ruedemann), Climacograptus innotatus (Nicholson), C. acanthodus (Ni) (=C. multispinus Wang
1983 and ?Paraclimacograptus sinitzini Chaletzkaja), Diplograptus fusus Wang have been recorded from this zone of Fenxiang and Huanghuachang sections (Wang et al., 1983a,b). The $G$. persculptus identified by Lin et Chen (1984. pl. 1, figs, 1-3) are generally poorly preserved and some are thought to be similar to those of Bornholm, Denmark (Bjerreskov, 1975), which have a fairly narrow rhabdosome and a low thecal count. In comparison with Williams (1983), it is unclear whether the latter may be assigned to $G$. persculptus s.s. The G. persculptus Zone of the present area may with the exception of the underlying $0.7 \mathrm{~m}$ thick black shale intercalated with thin-beded metabentonite containing $G$. ?'venustus cf. venustus', be correlated with the wellknown uppermost Ordovician same name zone of English Lake District (Hutt, 1975), and of Dob's Linn, Scotland (Williams, 1983). 
The Parakidograptus acuminatus Zone

This zone characterized by the presence of $P$. acuminatus is represented by the greyish-black thin bedded siliceous rock with shale. At Wangjiawan section its thickness is $0.63 \mathrm{~m}$. The following graptolites have been obtained from the exposures: Akidograptus ascensus, Climacograptus acanthodus $(\mathrm{Ni}), C$. rectangularis M'Coy, $C$. medius Törnquist, $C$. innotatus (Nicholson), Diplograptus modestus Lapworth. It is easily correlated with the corresponding acuminatus Zone from Bornholm, Denmark and northern Canadian Cordillera (Lenz, 1982) as well as from Britain, and from Mirny Creek and Kazakhstan, USSR (Koren et al., 1979; Apollonov et al., 1980).

\section{The Orthograptus vesiculosus Zone}

$P$. acuminatus Zone passes into the $O$. vesiculosus Zone without obvious lithological change. This zone is indicated by the disappearance of $P$. acuminatus and the appearance of abundant $O$. vesiculosus, along with Diplograptus modestus Lapworth, $D$. longiformis Wang, $D$. thuringiacus $(=D$. elongatus Churkin et Carterr), Climacograptus rectangularis $\mathrm{M}$ 'Coy, and $C$. normalis Lapworth. Its thickness is $2.6 \mathrm{~m}$. In the Fenxiang section the zone yields Atavograptus atavus (Jones). This graptolite assemblage and its stratigraphic position show that the $O$. vesiculosusZone of China is equivalent to the vesiculosus Zose redifined by Toghill (1968) at Dob's Linn with a 'acme-zone' character and may be correlated with the homonymous zone from Tongzi, Guizhou (Chen et Lin, 1978) and Guanyinqiao, Jijiang, Sichuan (Jin et al., 1982), and Alaska, N. American (Churkin et al., 1971) and with the $A$. atavus Zone of Britain (Rickards, 1976) and northern Cordilera (Lenz, 1982).

\section{The Lagarograptus acinaces Zone}

No marked lithological change is seen between this zone and the $O$. vesiculosus Zone. The $L$. acinaces Zone is characterized by the appearance of $L$. acinaces (Törnquist) and Coronograptus leei (Hsü) in association with Monograptus? changyagensis Sun, Diplograptus mucroterminatus Churkin et Carter ( = D. acuminatus Wang, 1977), $D$. diminatus $\mathrm{E}$. et $\mathrm{W}$., and $D$. bifurcus $\mathrm{Mu}$ et al. (? $=D$. coremus Chen et Lin, 1978). L. acinaces is chosen as zonal designation in place of the origi- nal $C$. leei Zone since $C$. leei ranges through the $L$. acinaces, $C$. cyphus Zones and even higher levels. The $L$. acinaces Zone here is likely correlative to the same name zone of Britain, northern Canada and USSR (Koren, 1973).

\section{The Coronograptus cyphus Zone}

This zone of the Longmaxi Formation near Loreiping Village was first reported by $\mathrm{Mu}$ (1959). This species is quite frequent in the equivalent level on Lipeng, Yidu County (Wang, 1984), but has not been found at the Wangjiawan section. The zone is characterized by the appearance of Monograptus? revolutus (Kurck), Pernerograptus cf. austerus (Törnquist) and Monoclimacis luncta Chen et Lin at the Wangjiawan section. The appearance of Demirastrites triangulatus marks the end of this zone. Both $M$. ? revolutus and $P$. austerus are representive elements of the $C$. cyphus Zone elsewhere in the world. $M$. luncta is also disignated as an equivalent zonal fossil to $C$. $c y$ phus in Guizhou (Chen et Lin, 1978). The graptolites associated with them, Diplograptus microterminatus Churkin et Carter, D. thuringiacus Eisel, Coronograptus cf. gregarius (Lapworth), Logarograptus cf. acinaces (Törnquist), Glyptograptus enodus Packham, are all common elements of the $C$. cyphus Zone. The $C$. cyphus Zone of present area, therefore, is regarded as equivalent to the homonymous zone from Britain, Alaska of North American and USSR, as well as to the $C$. gregarius Zone of northern Cordillera (Lenz, 1982) and the upper part of the $M$. ?revolutus Zone from Bornholm, Denmark (Bjerreskov, 1975).

\section{The Demirastrites triangulatus Zone}

This zone is about $12.6 \mathrm{~m}$ thick at the Wangjiawan section. Its lithological characteristic is similar to that of the underlying $C$. cyphus Zone. The greyish black shale is rich in graptolites. The zone is defined by the disappearance of $C$. cyphus and $M$. ? revolutus and the appearance of $D$. triangulatus. Associated graptolites are Diplograptus mucroterminatus Churkin et Carter, D. thuringiacus Eisel, Glyptograptus cf. sinuatus (Nicholson), Pseudoglyptograptus retroversus (Bulman et Rickards), Oktavites communis (Lapworth), Petalolithus cf. folius (Hisinger). This graptolite assemblage indicated that the zone here probably correlates with the same name zone of Britain 
(Hutt, 1974; Rickards, 1976) and northern Canadian Cordillera (Lenz, 1982) and the lower $C$. gregarius Zone of Bornholm, Denmark (Bjerreskov, 1975).

The Diplograptus magnus- $D$. thuringiacus Zone This zone, which is $15.2 \mathrm{~m}$ thick in the Wangjiawan section, is marked by the appearance of $D i$ plograptus thurinjiacus. Other common graptolites comprise Pribylograptus leptotheca (Lapworth), P. cf. argutus (Lapworth) and Pseudoglyptograptus retroversus (Bulman et Rickards). Diplograptus cf. magnus was obtained from the more or less identical level of Gaolou, Ensi City. It is similar to $D$. thuringiacus in the characteristics of rhabdosome and thecae, and differs only in that the latter is bigger. Whether the two species are synonymous is worth considering. Since this assemblage is situated between the $D$. triangulatus and $P$. argenteus Zones, it is likely equivalent to the $D$. magnus Zone of Britain.

\section{The Pernerograptus argenteus Zone}

This zone, which is situated in the toppest Black Shale Member of Wangiiawan section, is about $5.6 \mathrm{~m}$ thick. It is characterized by incoming of Pernerograptus cygneus (Törnquist). $P$. cf. argenteus was only found at the neighboring Fenxiang section. The common graptolites are Pernerograptus difformis (Törnquist), P. austerus bicornis (Hutt), P. cf. austerus sequence (Hutt), Paramonoclimacis sinicus (Geh), Rastrites phleoides (Törnquist), Orthograptus cf. cyperoides (Törnquist), Diplograptus thuringiacus Eisel, Pseudoglyptograptus retroversus (Bulman et Rickards),
Climacograptus scalaris (Hisinger). argenteus and cygneus are typical elements for the $P$. argentues Zone of Britain, moreover, Hutt (1975) has shown that cygneus is a junior synonym of argenteus. $P$. difformis, $P$. austerus bicornis, $P$. cf. austerus sequence, on the other hand, are mainly recorded from the $D$. triangulatus and $D$. magnus Zones of Britain (Hutt, 1974). Accordingly, whether the $P$. argenteus Zone of the study area can be correlated with the same zone elsewhere in the world and whether its boundary coincides with the underlying $D$. magnus- $D$. thuringiacus Zone is worth further study. It is suggested that the Black Shale Member at the Wangjiawan section is correlative with the Rhuddanian to lower Idwian (B1-B2).

\section{Yellowish-green Shale Member}

This member consists of yellowish-green shale, and sandy shale with a few sandstone bands, and contains graptolites and few shelly fossils. Its thickness is $571.4 \mathrm{~m}$. The following three graptolite zones, Demirastrites convolutus, Monograptus sedgwickii and Coronograptus ?arcuatus (= Monoclimacis arcuata) zones can be recognized. The uppermost zone can, however, range up to the Loreiping Formation.

\section{The Demirastrites convolutus Zone}

This zone, which is $51.9 \mathrm{~m}$ thick, readly correlates with the same name zone all over the world since the graptolite assemblages are similar. The $D$. convolutus Zone at Wangjiawan section is marked by the incoming of $D$. convolutus (Hisinger), D. decipiens (Törnquist), Streptograptus

Explanation of Plate 1

Fig. 1. Glyptograptus persculptus Salter X9, the G. pesculptus Zone, Fenxiang section, Yichang, Hubei.

Fig. 2. Parakidograptus acuminatus (Nicholson) X6, the P. acuminatus Zone, Wangjiawan section, Yichang, Hubei.

Fig. 3 Akidograptus ascensus Davies X3, the P. acuminatus Zone, Huanghuachang section, Yichang, Hubei.

Fig. 4. Diplograptus thuringiacus Eisel X5, the D. convolutus Zone, Wangjiawan section, Yichang, Hubei.

Fig. 5. Orthograptus vesiculosus (Nicholson) $(=$ Cystograptus vesiculosus) X3, the $O$. vesiculosus Zone, Fenxiang section, Yichang, Hubei.

Fig. 6. Climacograptus nebula (Toghill et Strachan) X10, the Member 1 of the Shamao Formation, Wangjiawan section, Yichang.

Fig. 7. Monograptus sedgwickii (Portlock) X5, the M. sedgwickii Zone, Wangjiawan section, Yichang, Hubei.

Fig. 8. Pseudoglyptograptus retroversus (Bulman et Rickards) X10, the D. convolutus Zone, Wangjiawan section, Yichang, Hubei.

Figs. 9-10. Diplograptus cf. magnus H. Lapworth X3, the D. magnus- D. thuringiacus Zone, Gaoluo section, Xuanen, Hubei. 

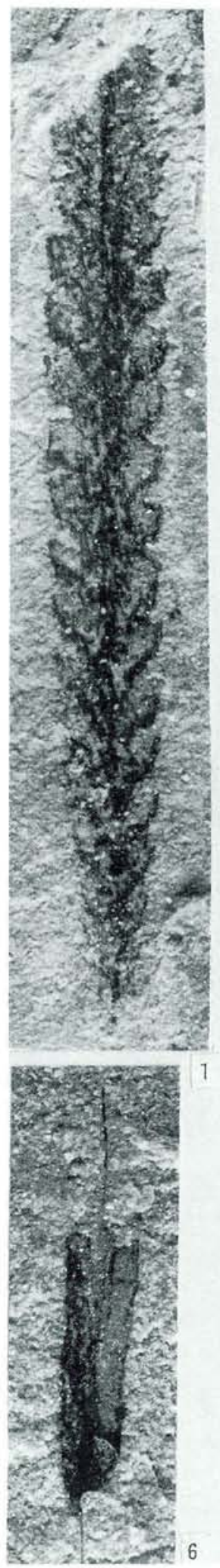
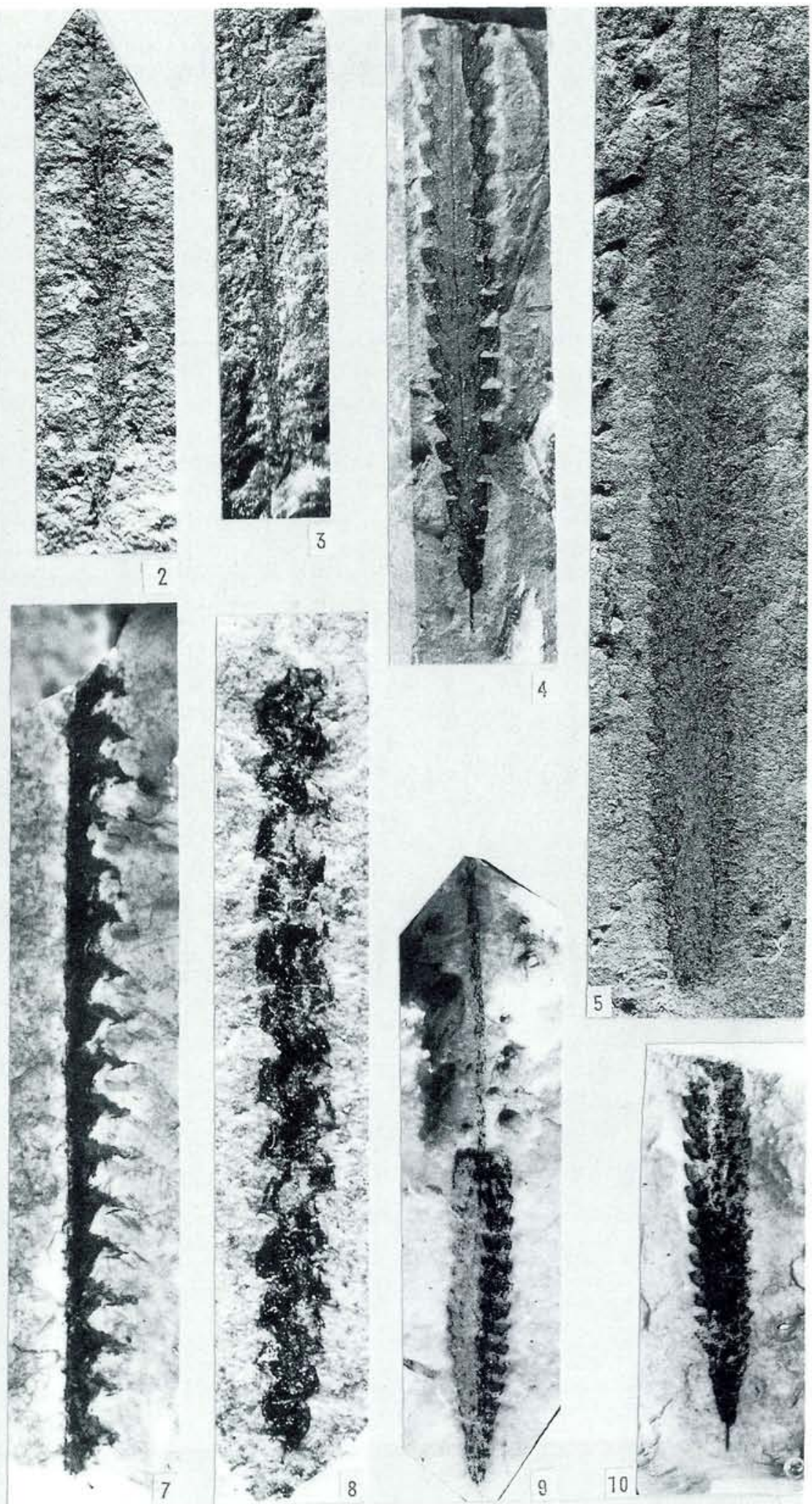
?lobiferus (M'Coy), S. lobiferus harpago (Törnquist), Diversograptus ramosus Manck, Glyptograptus elegans Packham, Oktavites communis (Lapworth), and Petalolithus ovato-elongatus (Kurch).

The Monograptus sedgwickii Zone

This zone is $138.9 \mathrm{~m}$ in thickness. It is characterized by the presence of $M$. sedgwickii (Portlock) at the Wangjiawan section. Other graptolites comprise Glyptogratus incertus Elles et Wood, Demirastrites decipiens (Törnquist) and Pernerograptus cygneus (Törnquist). This graptolite assemblage is very close to that of corresponding M. sedgwickii Zone from Britain, Northern Canadian, USSR and Alaska of North American.

\section{The Coronograptus ?arcuatus Zone}

This zone ranges from the uppermost part of the Yellowish-green Shale Member into the lower part of the overlying Loreiping Formation. The C. ?arcuatus Zone is divisible into Lower and Upper units. The Lower $C$. ?arcuatus Zone is difined by the appearance of the nominal species, the absence of $M$. sedgwickii at the Wangjiawan section. Associated graptolites are Pseudoglyptograptus retroversus (Bulman et Rickards), Glyptograptus incertus Elles et Wood, Climacograptus simplex Rickards, and Oktavites communis obtusus (Rickards). These graptolites all are of common elements of the $M$. sedgwickii Zone and the last two species are usually recorded in the middle part of the $M$. sedgwickii Zone of Britain (Rickards, 1976). The Lower C. ?arcua- tus Zone is, therefore, probably coeval with the middle part of Britain $M$. sedgwickii Zone, while underlying Monograptus sedgwickii Zone of the present area is correlative with only the lower part of British sedgwickii Zone. The thickness of the lower $C$. ?arcuatus Zone is $303.5 \mathrm{~m}$.

\section{Loreiping Formation}

Lower Member : Upper C. ?arcuatus Zone This member is composed of yellowish-green calcareous silty mudstone with nodular biogenic marl, containing abundant brachipods, trilobites, corals, conodonts and a few cephalopods and graptolites. Its thickness is $103 \mathrm{~m}$. The dominant graptolites are Coronograptus ?arcuatus (Mu et al.), Glyptograptus elegans Packham, G. serratus Elles et Wood, Climacograptus simplex Rickards, Pseudoglyptograptus retroversus (Bulman et Rickards), and Pristiograptus regularis (Törnquist). This assemblage suggests that the Upper C. ? arcuatus Zone probably corresponds to the upper part of British $M$. sedgwickii Zone. In view of this, the boundary between the Longmaxi and Loreiping Formations roughly coincide with the boundary between the middle and upper parts of British M. sedgwickii Zone.

\section{Upper Member}

The member is composed of yellowish-green thin-bedded siltstone, silty mudstone, with 45.9 $\mathrm{m}$ thick, containing various shelly fossils. Its top and bottom are marked by the presence of bio-

Explanation of Plate 2

Fig. 1. Monograptus cf. drepanoformis Toghill et Strachan X5, the Member 2 of the Shamao Formation, Wangjiawan section, Yichang.

Fig. 2 Demirastrites cf. triangulatus (Harkness) X10, the D. triangulatus Zone, Wangjiawan section Yichang, Hubei.

Fig. 3. Demirastrites triangulatus (Harkness) X3, the D. triangulatus Zone, Fenxiang section, Yichang, Hubei.

Fig. 4. Lagarograptus cf. acinaces (Törnquist) X5, the L. acinaces Zone, Wangjiawan section, Yichang, Hubei.

Fig. 5. Demirastrites convolutus (Hisinger) X5, the D. convolutus Zone, Wangjiawan section, Yichang, Hubei.

Figs. 6,8. Climacograptus nebula (Toghill et Strachan) X10, the Member 1 of the Shamao Formation, Wangjiawan section, Yichang.

Figs. 7,10. Monograptus marri Perner X3, Fig. 7 is a part of the opposite aspect of the Fig. 10, the Member 2 of the Shamao Formation, Wangjiawan section, Yichang, Hubei.

Fig. 9. Pernerograptus cf. argenteus (Nicholson) XS, the P. argenteus Zone, Fenxiang section, Yichang, Hubei.

Fig. 11. Monograptus ?revolutus (Kurck) X5, the C. cyphus Zone, Fenxiang section, Yichang, Hubei. 

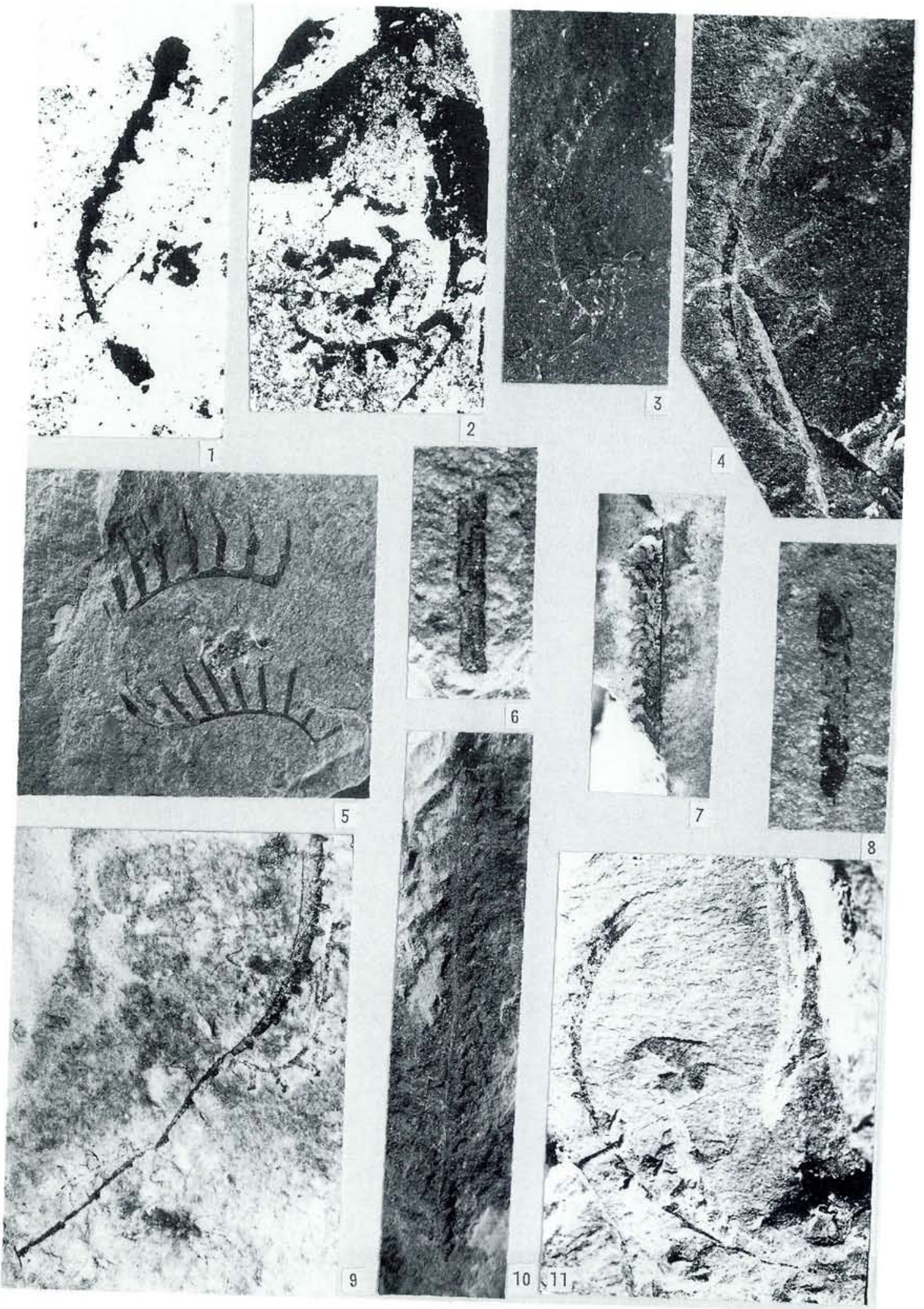
genic limestone containing Pentamerus and is easily distinguished from the overlying and underlying strata. The Upper Member of the Loreiping Formation lies between the Upper $C$. ?arcuatus Zone of the Lower Member and the Member 1 of the Shamao Formation with Climacograptus nebula (Toghill et Strachan) (=Retioclimacis typica $\mathrm{Mu}$ ). Although no graptolite have been found, the interval is likely to be equivalent to the most part of the $S$. turriculatus Zone, of the upper Fronian (C2-3) stage.

\section{Shamao Formation}

The age of the Shamao Formation has been a controversial and unresolved problem for a long time. The Shamao Formation of this paper is same as the original Shamaoshan beds proposed by Xie and Chao (1925) except that the upper unit of the original definition is now proven to be the Middle Devonian Yuantaiguan Formation. Lithologically, four members can be recognized. Member 1 and 3 consist of mudstone and siltstone, while member 2 and 4 are characterized by sandstone and siltstone.

\section{Member 1}

This member is characterized by yellowish-green silty mudstone intercalated with siltstone and is $77.4 \mathrm{~m}$ in thickness. It contains shelly fossils and graptolites, the latter is represented by Climacograptus nebula (Toghill et Strachan) (= Retioclimacis typica $\mathrm{Mu}$ et al.), Pristiograptus variabilis (Perner), Monograptus cf. drepanoformis Toghill et Strachan, and Oktavites planus (Barrande)?. $C$. nebula was first discovered from the M. griestoniensis Zone of Grieston Quarry, near Innerleithen, Peebleshire, Britain (Toghill and Strachan, 1970), and subsequently was reported from the turriculatus-griestoniensis Zone of English Lake District and Howgill Fells (Hutt, 1974), and from the corresponding level on Bornholm, Denmark (Bjerreskov, 1975). These graptolites indi- cate that Member 1 of the Wangjiawan section may be equivalent to the upper turriculatus and lower crispus Zones.

\section{Member 2}

Member 2 comprises a set of yellowish-green and greyish-green thin bedded siltstone, and fine sandstone, intercalated with sandy shale and shale. Its thickness is $118 \mathrm{~m}$. The base is marked by the incoming of very red mudstone bands. Its top is readily drawn at the appearance of a thin $(0.93 \mathrm{~m})$ band of brown ferruginous calcareous sandstone, containing conodonts and fragments of trilobites. The following graptolites are found in the lower and middle parts of this member at the Wangjiawan section: Monograptus cf. drepanoformis Toghill et Strachan, M. marri Perner, Monoclimacis sp., Pristiograptus variabilis (Perner), Pr. wulongguanensis Wang sp.n., and Petalolithus cf. minor Elles. M. drepanoformis is a principal element of the $M$. griestoniensis Zone of the Grieston Quarry, Britain (Toghill et Strachan, 1970). $M$. marri is a common element in the turriculatus to crispus Zones of Britain. Pr. regularis and $P e$. cf. minor usually appear in a lower stratigraphic level elsewhere in the world. The graptolite fauna suggests that Member 2 is equivalent to the upper crispus to griestoniensis Zones of Britain. Hun (1958) reported that a late Silurian graptolite fauna had been discovered from the Wulongguan near Loreiping, Yichang. A reexamination of Hun's collections and the acquisition of new material suggests that the fauna is typical of Member 2 of the Wangjiawan section. Specimens identified as Monograptus bohemicus, and $M$. nilssoni are, in fact, Pr. regularis and Pr. variabilis, respectively, while Monograptus uncinatus cf. var. micropoma, $M$. dubius and $M$. colonus are thought to identical with $P r$. wulongguanensis Wang sp.n.

\section{Member 3}

Overlying Member 2 is a $284 \mathrm{~m}$ thick sequence of yellowish or greyish-green shale, and sandy shale

Explanation of Plate 3

Figs. 1,4. Coronograptus ?arcuatus (Mu et al.) X20, the C. ?arcuatus Zone, Fenxiang section, Yichang, Hubei.

Fig. 2. Coronograptus cyphus praematures (Toghill) X10, the ?vesiculosus Zone, Liping, Yidu, Hubei.

Fig. 3. Demirastrites convolutus (Hisinger) X3, the D. convolutus Zone, Gaoluo section, Xuanen, Hubei. 

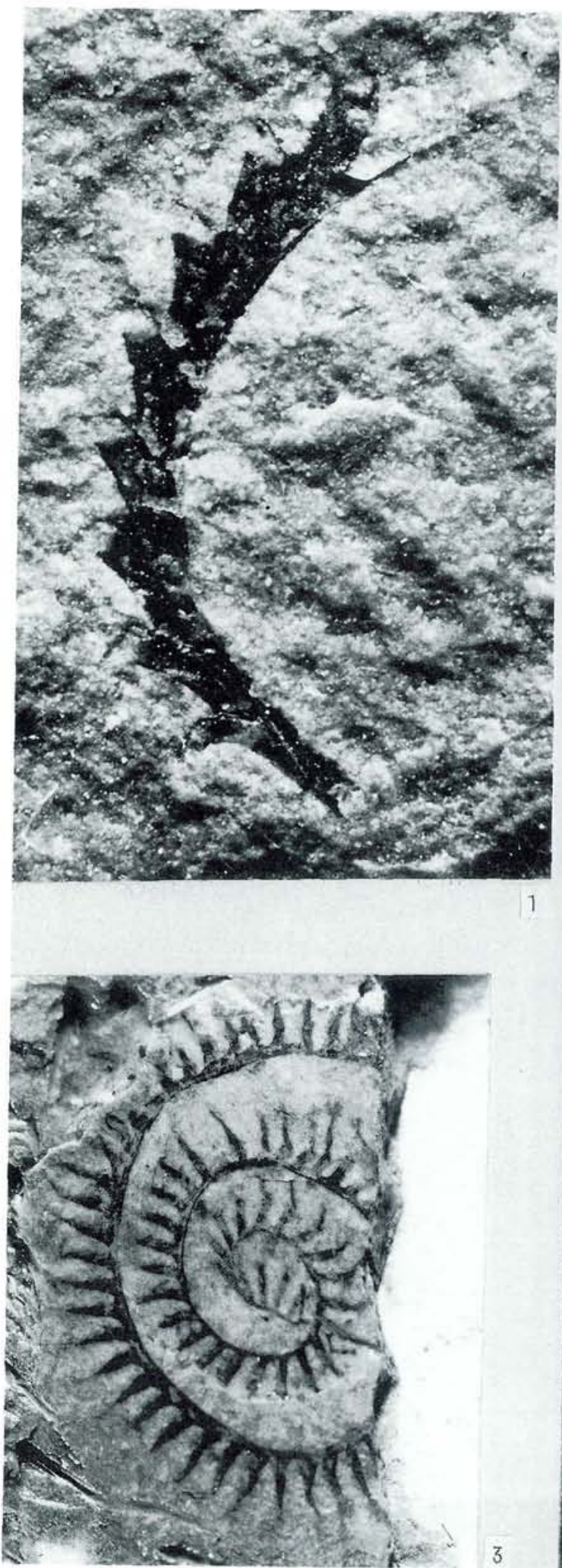

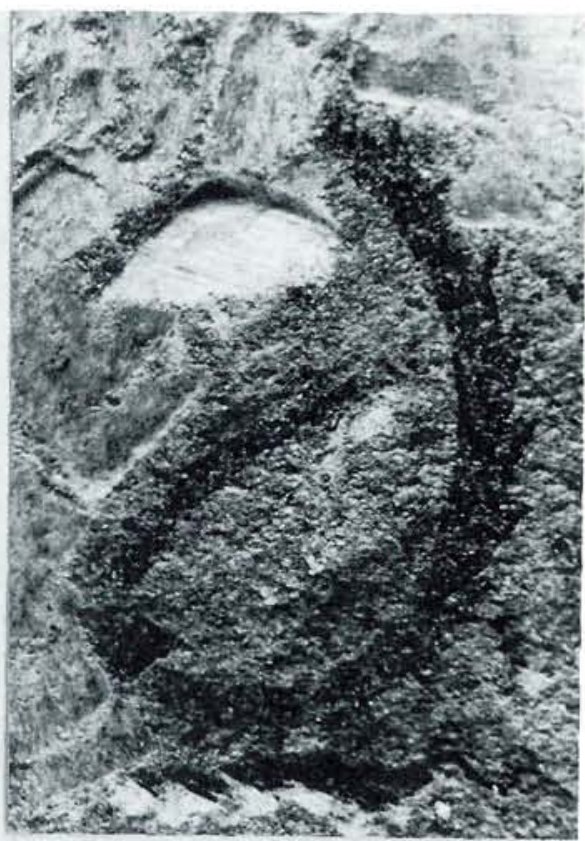

5

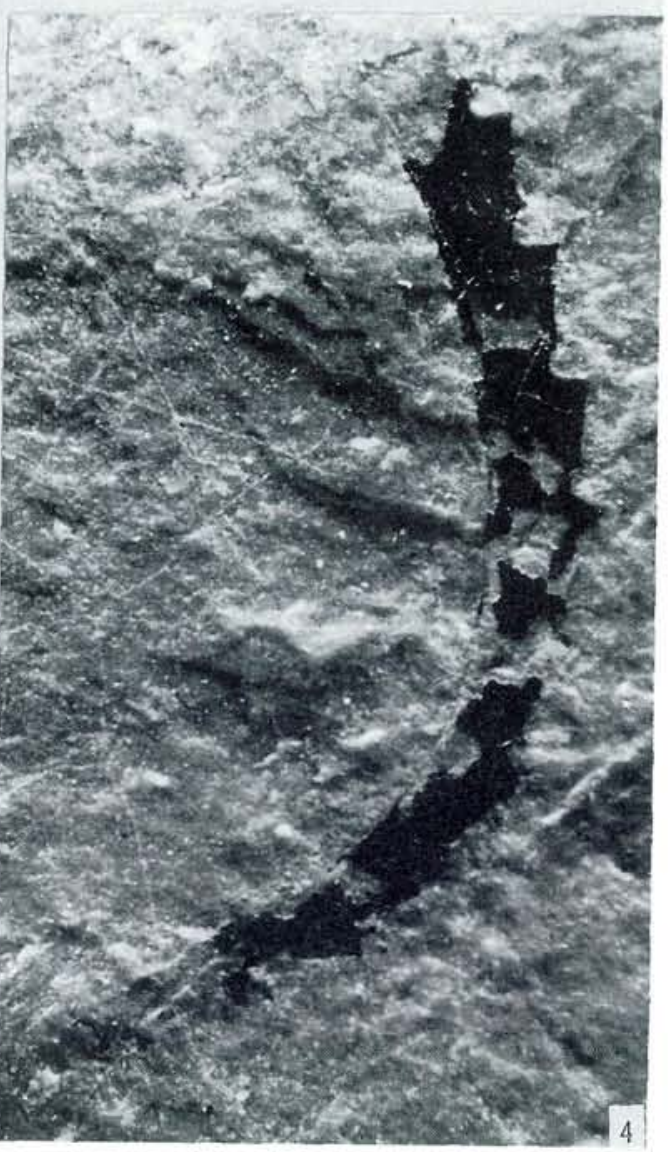


with a few bands of argillaceous siltstone, designated Member 3. Its fauna includes a few brachiopods, bivalves, trilobites and the graptolite Dictyonema wangjiawanensis Wang sp.n. Since the shelly fossils found here are similar to those of the upper Xiushan Formation which contains Stomatograptus sinensis Wang (Ge et al., 1979), the age of Member 3 is likely to be of the latest early Silurian or earliest middle Silurian.

\section{Member 4}

The highest member of the Shamao Formation is composed of greyish-green and very red barren medium bedded fine-grained quartz sandstone and siltstone intercalated with sandy shale. Its thickness is $185.3 \mathrm{~m}$ at the Wangjiawan section. This member is readily distinguished from the yellowish-green sandy mudstone at the top of the Member 3 by greyish-green medium bedded sandstone in the lower part of this member. Its top lies unconformably beneath the grey quartzite with gravels which characterizes the base of the Middle Devonian Yuantaiguan Formation. Based on the lithology and stratigraphic position, the age of Member 4 may be equivalent to the Huixinshao Formation in Rongxi and Xiushan of Sichuan and Shiqian of Guizhou, that is early middle Silurian. The correlation of the graptolite sequence from the Longmaxi Formation to the Shamao Formation of the eastern Yangzi Gorges with other regions of the world is shown in table 1.

\section{The graptolite sequence across the Ordovician-Silurian boundary}

There are three Ordovician-Silurian boundary sections, near Yichang, as reported by Wang et al. (1980, 1983a,b): (1) Huanghuachang section,

Table 1. Correlation of the graptolite sequence from the Longmaxi to the Shamao Formation in the eastern Yangzi Gorges, China with other regions of the world.

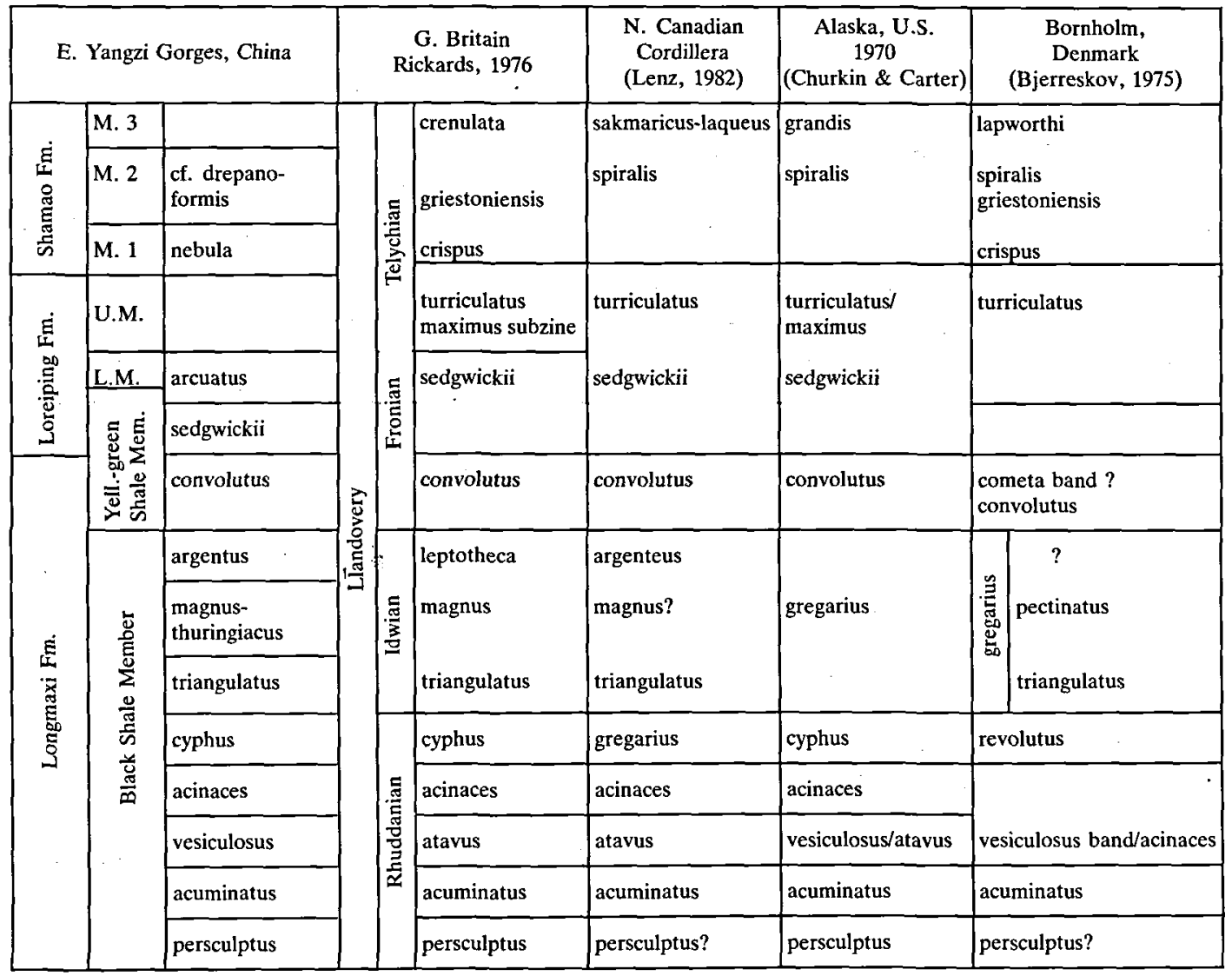


Table 2. The correlation of the latest Ordovician-earliest Silurian biostratigraphic succession from the eastern Yangsi Gorges with other places of the world.

\begin{tabular}{|c|c|c|c|c|c|c|c|}
\hline \multicolumn{2}{|c|}{ E. Yangzi Gorges } & \multicolumn{2}{|r|}{$\begin{array}{c}\text { Dob's Linn, } \\
\text { Scotland } \\
\text { (Williams, 1982, 1983) }\end{array}$} & $\begin{array}{c}\text { Darraweit Guim } \\
\text { Australia } \\
\text { (VandenBerg } \\
\text { et al., 1984) }\end{array}$ & $\begin{array}{c}\text { Kolyma, Siberia \& } \\
\text { Kazakhstan, USSR } \\
\text { (Koren et al.) } \\
1977,1980\end{array}$ & $\begin{array}{l}\text { N. Cordillera, } \\
\text { Canada } \\
\text { (Lenz et } \\
\text { McCracken, 1982) }\end{array}$ & $\begin{array}{c}\text { Barrandian, } \\
\text { Bohemia } \\
\text { (Storch, 1982) }\end{array}$ \\
\hline \multirow{2}{*}{ 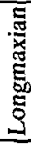 } & P. acuminatus & \multirow{3}{*}{ 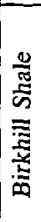 } & P. acuminatus & \multirow{2}{*}{$\begin{array}{l}P . \text { acuminatus } \\
\text { G. persculptus }\end{array}$} & P. acuminatus & P. acuminatus & P. acuminatus \\
\hline & G. persculptus & & G. persculptus & & $?$ & G. persculptus & $\begin{array}{c}\text { A. ascensus } \\
?\end{array}$ \\
\hline \multirow{5}{*}{ 竞 } & $\begin{array}{l}\text { Hirnantia- } \\
\text { Kinnella }\end{array}$ & & G.?'venustus' & \multirow{2}{*}{$\begin{array}{l}\text { C.?extraordi- } \\
\text { narius }\end{array}$} & \multirow{2}{*}{$\begin{array}{l}\text { D. bohemicus (= } \\
\text { G. persculptus } \\
\text { forma B) } \\
\text { C. ?extraordi- } \\
\text { narius }\end{array}$} & & \multirow{2}{*}{$\begin{array}{l}\text { (D. aff. bohemicus) } \\
\text { Himantia } \\
\text { fauna } \\
\text { D. bohemicus }\end{array}$} \\
\hline & D. bohemicus & \multirow{4}{*}{ 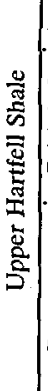 } & \multirow{4}{*}{ 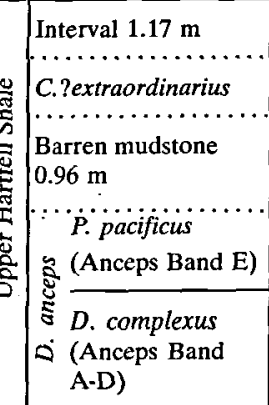 } & & & $\begin{array}{l}\text { Conodont } \\
\text { fauna } 12\end{array}$ & \\
\hline & $\begin{array}{l}\text { Paraorthograptus- } \\
\text { D. mirus }\end{array}$ & & & $?$ & $?$ & \multirow{3}{*}{ P. pacificus } & \multirow[t]{3}{*}{ no fossils } \\
\hline & T. typicus & & & \multirow{2}{*}{$\begin{array}{l}\text { D. ornatus- } \\
\text { C. latus }\end{array}$} & \multirow[t]{2}{*}{ P. pacificus } & & \\
\hline & $\begin{array}{l}\text { D. szechuanensis } \\
(=\text { D. complexus })\end{array}$ & & & & & & \\
\hline
\end{tabular}

(2) Fenxiang section, and, especially (3) Wangjiawan section, which are the best potential candidates for the choice of an international Ordovician-Silurian boundary stratotype. In these sections the following eight zones can be recognized in the Wufeng Formation and basal Longmaxi Formation: D. szechuanensis (=D. complexus), T. typicus, Paraorthograptus- D. mirus, D. bohemicus, Hirnantia-Kinnella, G. persculptus, $P$. acuminatus and $O$. vesiculosus Zones.

The suggestion that $D$. szechuanensis is conspecific with $D$. complexus Davies and that Paraorthograptus typicus $\mathrm{Mu}$ and other species of Paraorthograptus are conspecific with $P$. pacificus Ruedemann (Williams, 1982) are being serious consideraton by Chinese graptolite students. Ongoing studies the Paraorthograptus uniformis Zone (proposed by Mu 1974 and Mu et al. 1984) show that it is difficult to recognize and that even the index species is probably synonymous with $P$. pacificus even though present author previously recogzized it (Wang et al., 1983b). It should be noted, however, that Paraorthograptus pacificus is long ranging and is difficult to use for worldwide correlation as done by Williams (1983). The fact that Dicellograptus anceps has been found at the base and top of the D. szechuanensis Zone, and that $D$. szechuanensis may be conspecific to $D$. complexus suggests that the $D$. complexus Subzone as well as the basal $P$. pacificus Subzone with $D$. aff. complexus (Anceps Band D at Dob's Linn section, Scotland is correlative with the $D$. szechuanensis Zone of the eastern Yangzi Gorges. The fission track date of a bentonite layer near the top of the $D$. szechuanensis Zone is $447 \pm 10$ m.y. (Wang et al., 1980; Ross et Naeser, 1984). Most graptolites reported from the upper part of the $P$. pacificus Subzone (Anceps Band E) at Dob's Linn section by Williams (1982), such as Dicellograptus graciliramosus (= D. minor), Climacograptus longispinus supernus, Orthograptus abbreviatus, Paraplegmatograptus uniformis (= Plegmatograptus ? craticulus), Paraorthograptus pacificus, Pleurograptus lui and Pararetiograptus regularis ( $=$ Orthoretiograptus denticulatus Wang et al. of Williams, 1982), have been recorded from the $T$. typicus Zone of the eastern Yangzi Gorges. Furthermore, $P$. lui is found only in the $D$. szechuanensis and $T$. typicus Zones. It is suggested, therefore, that the upper part of the $P$. pacificus Subzone (Anceps Band E) at Dob's Linn section is possibly correlative with all or part of the T. typicus Zone. It should not overlooked that an interval of unfossiliferous 
pale grey mudstone, $0.96 \mathrm{~m}$ thick is sandwiched between the Anceps Band E (i.e. the top of the P. pacificus Subzone) and a thin brown Extraordinarius Band at Dob's Linn section. An similar nonfossiliferous gap also exists between the $P$. pacificus and $C$. ?extraordinarius $(=G$. ?persculptus forma A) Zones at Mirny Creek and Kazakhstan sections, USSR (Koren et al., 1979; Apollonov et al., 1980) and at Darraweit Guim, central Victoria (Vandenberg et al., 1984). It is this interval which may be equivalent to the Paraorthograptus $-D$. mirus Zone and possibly the top of the $T$. typicus Zone in the present area. The occurrence of $C$. ?extraordinarius and related species in the $D$. bohemicus Zone suggests that the $D$. bohemicus Zone and the overlying Hirnantia-Kinnella Zone of the eastern Yangzi Gorges may correlate with the $C$. ?extraordinarius Zone at Dob's Linn section, Scotland and possibly with the overlying pale grey mudstone of $1.17 \mathrm{~m}$ thick and even the $0.56 \mathrm{~m}$ thick black shale with $G$. ?'venustus venustus' at the base of Birkhill Shale. They are also probable correlatives of the $C$. ?extraordinarius and $D$. bohemicus ( $=$ G. ?persculptus forma B) Zones of USSR.

The correlation of the Ordovician-Silurian biostratigraphic succession between the Wangjiawan section and other places of the world is shown in table 2.

The researches on the Ordovician-Silurian boundary in the eastern Yangzi Gorges suggest it more reasonable to fix the boundary at the base of the $G$. persculptus Zone, i.e. between the $G$. persculptus and Hirnantia-Kinnella Zones. In order to respect the decision ratified by the Commission of Stratigraphy and IUGS, however, the Ordovician-Silurian boundary is, unfortunately, drawn at the base of the Parakidograptus acuminatus Zone.

Acknowledgments. I am very grateful to Drs. Ni Shazhao, Zeng Qinglung, Xu Guanghong, Zhou Tianmei and Mr. Li Zhihong for their cooperation in field work and helpful advice in the subdivision and correlation of the Silurian deposits. I also wish to give my sincere thanks to Prof. A. C. Lenz and Dr. R. B. Rickards for critically reading of the manuscript. The manuscript has been improved from their valuable advice.

\section{Dansk sammendrag}

De silure aflejringer, der er blottet i flodbrinkerne ved Yangzi opdeles $i$ tre formationer: Longmaxi, Loreiping og Shamao. I Longmaxi Formationen samt det nederste led i Loreiping Formationen kan følgende graptolitzoner udskilles: persculptus, acuminatus, vesiculosus, acinaces, cyphys, triangulatus, magnus-thuringiacus, argenteus, convolutus, sedgwickii og arcuatus. De »sene silure « graptolitter, der har varet rapporteret fra den nedre del af Shamao Formationen, revideres i dette arbejde. På et tilsvarende stratigrafisk niveau er der fundet $C$. nebula, $M$. cf. drepanoformis, $P$. variabilis og $M$. marri. Graptolit sekvensen hen over ordivicium-silur grænsen og dens internationale korrelation diskuteres.

\section{References}

Apollonov, M. K., Bandaletov, S. M., Niktin, I. F. (eds): 1980. The Ordovician-Silurian boundary in Kazakhstan. Academy of Science of the Kazakh SSR., 'Nauka' Kazakh SSR publishing House, Alma-Ato, 300 pp. (in Russia).

Bjerreskov, M., 1975: Llandoverian and Wenlockian graptolites from Bornholm, Fossils and Strata, 8. $94 \mathrm{pp}$.

Chen Xu \& Li Yao-kun: 1978. Lower Silurian graptolites from Tongzi, Northern Guizhou, Mem. Nanjing Inst. Geol. \& Palaeont., Acad. Sinica, 12, 1-76.

Churkin, M. Jr., Carter, C. \& Eberlein, C. D. 1971: Graptolite succession across the Ordovician-Silurian boundary in south-eastern Alaska, Q. Jour. Geol. Soc. London, 126, 319-330.

Ge Zhi-zhou, Rong Jia-yu, Yang Xue-zhang, Liu Geng-wu, Ni Yu-nan, Dong Dei-yuan \& Wu Hong-ji. 1979: The Silurian system in south-western China. In: Biostratigraphy of the Carboniferous strata in south-western China. Nanjing Inst. Geol. \& Palaeont. (ed.). Science press, 155-220 (in Chinese).

Hsich, C. Y. \& Chao, Y. T. 1925: A study of the Silurian section at Lojoping, Ichang District, Bull. Geol. Soc. China, 4, 39-44.

Hsü, S. C. 1934: Graptolites of Lower Yangtze Valley, Monogr. S. A., IV, Inst. Geol. Acad. Sinica, 106 p.

Hun Yuan-cun. 1958: Ludlovian Graptolite fauna of the Yangtze Gorges District and their stratigraphical significance, Acta Palaeont. Sinica, 6(1), 90-116.

Hutt, J. E. 1974: The Llandovery graptolites of the English Lake District, Palaeontogr. Soc. Monogr., 2, 1-56.

Jin Chuntai, Ye Shaohua, He Yanxiang, Wan Zhengquan, Wang Shubei, Zhao Yuting, Li Shanji, Xu Xingqi \& Zhang Zhengui. 1982: The Silurian stratigraphy and palaeontology in Guanyinqiao, Qijiang, Sichuan, People's pub. House of Sichuan, 1-84 (in Chinese).

Koren, T. N. 1973: The Silurian and Lower Devonian graptolite-bearing strata in the USSR (a review), Geol. Mag., 110, 1-17.

Koren, T. N. \& Sobolevskaya, R. F. 1977: A new standard succession of graptolite assemblage at the Ordovician-Silurian boundary, North-eastern USSR, Dokl. Akad. Nauk. SSSR, 236(4), 950-953.

Koren, T. N., Sobolevskaya, R. F., Mikhajlava, N. F. \& Tsai, D. T. 1979: New evidence on graptolite succession across the Ordovician-Silurian boundary in the Asia part of the USSR, Acta Palaeont. Pol. 24(1), 125-136.

Lee, C. C. \& Chao, Y. T. 1924: Geology of the Gorges District of the Yangtze (from Ichang to Tzekuei) with special reference to the development of the Gorges, Bull. Geol. Soc. China, 3, 351-391. 
Lenz, A. C. 1982: Llandoverian Graptolites of the Northern Canadian Cordillera: Petalograptus, Cephalograptus, Rhaphidograptus, Dimorphograptus, Retilitidae, and Monograptidae, Royal Ontario Museum, Life Sci. Contrib. 130, $1-154$.

Lenz, A. C. \& McCracken, A. D. 1982: The OrdovicianSilurian boundary, northern Cordillera, graptolite and conodont correlation, Can. J. Earth Sci., 19(6), 13081322.

Lin Yao-kun \& Chen Xu. 1984: Glyptograptus persculptus zone. - The Earliest Silurian Graptolite zone from Yangzi Gorges, China, In: Stratigraphy and Palaontology of Systematic Boundaries in China, Ordovician-Silurian Boundary (1), Nanjing Inst. Geol. \& Palaeont. (ed.), Anhui pub. House of Sci. \& Tech., 203-225.

Mu, A. T. 1959: Graptolite-bearing strata in China. Papers of special subject summary on the basic material of the Geology of China, 3, 1-75 (in Chinese).

Mu, A. T. 1962: The Silurian system in China. Compilation on the scientific reports of the first All-China stratigraphic congress, Science press, 1-95 (in Chinese).

Mu, En-zhi (Mu, A. T.), Zhu Zhao-ling, Lin Yao-kun \& Wu Hong-ji. 1984: The Ordovician-Silurian Boundary in Yichang, Hubei, In: Stratigraphy and Palaeontology of Systemic Boundaries in China, Ordovician-Silurian Boundary (1), Nanjing Inst. Geol. \& Palaeont. (ed.), Anhui pub House of Sci. \& Tech., 15-41.

Rickards, R. B. 1976: The sequence of Silurian graptolite zones in the British Isles, Geol. Jour., 11(2), 153-188.

Ross, R. Jr. \& Naeser, C. W. 1984: The Ordovician Time Scale-New Refinements, In: Bruton D. L. (ed.). 1984. As pects of the Ordovician System, 5-10, Pal. Cont. Univ. Oslo. 295, 5-10.

Storch, P. 1982: Ordovician-Silurian boundary in the northenmost part of the Prague Basin (Barrandian, Bohemia), Věstnik Ùstried ùst. geol., 53(4), 231-236.

Sun, Y. C. 1933: Ordovician and Silurian graptolites from China, Palaeontologia Sinica, 14(1), 1-69.

Toghill, P. 1968: The stratigraphical relationships of the earliest monograptidae, and the dimorphograptidae, Geol. Mag. $105,46-51$.

Toghill, P. \& Strachan, I. 1970: The graptolite fauna of the
Grieston quarry, near Innerleithen, Peebleshire, Palaeont. $13,511-521$.

VandenBerg, A. H. M., Rickards, R. B. \& Holloway, D. J. 1984: The Ordovician-Silurian boundary at Darraweit Guim, Central Victoria, Alcheringa, 8, 1-12.

Wang Xiaofeng. 1978: Silurian graptolites, In: Research Group of Stratigraphy of the Yangtze Gorges, Hubei Bureau of Geology (ed.), The Sinica-Permian Stratigraphy and Palaeontology from the eastern Yangtze Gorges, 232-250, Geol. Pub. House (in Chinese).

Wang Xiaofeng, Ni Shizhao \& Zhou Tianmei. 1980: Comments on the subdivision and correlation of the Ordovician System in the eastern Yangtze Gorges, Geol. Review, 26(4), 293-299 (in Chinese).

Wang Xiaofeng, Zeng Qingluan, Zhou Tianmei, Ni Shizhao, Xu Guanghong \& Li Zhihong. 1983a: Ordovician-Silurian Boundary Biostratigraphy of Eastern Yangtze Gorges, China, Scientia Sinica, B, 1124-1132 (in Chinese) and 1984 1, B, 101-112 (in English).

Wang Xiaofeng, Zeng Qingluan, Zhou Tianmei, Ni Shizhao, Xu Guanghong, Sun Quanying, Li Zhihong \& Xiang Liwen, Lai Caigen. 1983b: Latest Ordovician and earliest Sjlurian fauna from the eastern Yangtze Gorges, China with comments on Ordovician-Silurian boundary, Bull Yichang Inst. Geol. \& Min. Resour., Chinese Acad. Geol. Sci., 6, 85-163.

Wang Xiaofeng. 1984: Occurrence of Dicellograptus in Silurian strata, In: Scientific papers on Geology for International Exchange for the 27th International Geol. Congress, 1, 6974, Geol. Pub. House.

Williams, S. H. 1982: The late Ordovician graptolite fauna of the Anceps Bands at Dob's Linn, Southern, Geol. \& Palaeont., 16, 29-56.

Williams, S. H. 1983: The Ordovician-Silurian boundary graptolite fauna of Dob's Linn, southern Scotland, Palaeontology, 26, 605-639.

Yan Guoshun \& Wang Xiaofeng. 1978: The Silurian System, In: Research Group of Stratigraphy of the Yangtze Gorges, Hubei Bureau of Geology (ed.), The Sinica-Permian Stratigraphy and Palaeontology from the eastern Yangtze Gorges, 73-90, Geol. Pub. House. (in Chinese). 